Studia Judaica 24 (2021), nr 2 (48), s. 295-312

doi:10.4467/24500100STJ.21.013.15068

Alicja Maślak-Maciejewska iD https://orcid.org/0000-0002-2164-0344

Anna Trząsalska iD https://orcid.org/0000-0002-5035-8065

Maria Vovchko iD https://orcid.org/0000-0002-1882-2235

\title{
Żydówki nauczycielkami religii w Galicji do 1914 roku*
}

\author{
JEWISH WOMEN AS TEACHERS OF RELIGION IN GALICIA BEFORE 1914
}

\begin{abstract}
The article describes the activities of Jewish women teaching religion in Galician public schools. The first women performed this profession in the 1870 s, in the 1890 s they were listed for the first time in the schematisms (the official lists of civil servants), in the next decade the first woman received a permanent teaching position, and in 1913 they were for the first time directly addressed in the job announcement for teachers of religion. Therefore, their position became more established toward the end of the autonomous period, although they still constituted an absolute minority in this professional group.

The emergence of female teachers of religion raised protests among the male members of this professional group. They voiced three main arguments against granting women teaching positions: their alleged insufficient qualifications, the tradition of Judaism, and what they understood to be the "social justice" (according to which men deserved permanent teaching contracts more than women).

The article discusses the chronology of granting women the positions of teachers of religion, describes the public debate on the subject, and addresses the issue of women's professional qualifications. It is based on both printed and archival sources and on historical press.
\end{abstract}

Keywords: teaching religion, women, female teachers, public schools, Galicia.

Słowa kluczowe: religia w szkole, kobiety, nauczycielki, szkoła publiczna, Galicja.

* Artykuł powstał w ramach projektu Narodowego Centrum Nauki pt. „Religia mojżeszowa" jako przedmiot szkolny w Galicji: programy nauczania, podręczniki, nauczyciele, konkurs „Sonata” (2018/31/D/HS3/03604). Wszystkie autorki są członkiniami zespołu projektowego. Nazwiska autorek podano w kolejności alfabetycznej. 
W XIX w. „religia mojżeszowa” stała się jednym z przedmiotów nauczania wykładanych w galicyjskich publicznych szkołach świeckich. Już w pierwszej połowie tego stulecia zajęcia takie były organizowane przez pojedyncze szkoły średnie, w ostatniej zaś ćwierci wprowadzono je do szkół nauczających na poziomie podstawowym. Wiązało się to z objęciem w Galicji w 1873 r. wszystkich dzieci, w tym żydowskich, obowiązkiem szkolnym. Większość spośród nauczycieli religii stanowili mężczyźni. Pojawiały się jednak pojedyncze kobiety wykładające ten przedmiot.

Temat działalności Żydówek nauczycielek religii jest bardzo słabo rozpoznany w literaturze przedmiotu. Dekadę temu poświęcono mu jeden artykuł, jednak jego autor skupił się na międzywojniu, nie podając danych biograficznych nauczycielek z okresu autonomicznego ani szczegółów o ich działalności ${ }^{1}$. Nieco więcej informacji znajdujemy w literaturze jedynie na temat kobiet nauczających w tym okresie we Lwowie, chociaż też nie jest to ujęcie pełne, bo skoncentrowane na jednej szkole ${ }^{2}$. Niniejszy artykuł, oparty na zasobie źródłowym różnej proweniencji (drukowane dokumenty administracji, głównie szematyzmy, prasa pedagogiczna, archiwalia szkolne) jest próbą wstępnego rozpoznania tematu nauczania religii przez kobiety. Kompleksowe zbadanie tego zagadnienia wymagać będzie szeroko zakrojonych badań w archiwach gmin żydowskich i aktach szkolnych. Informacje o żydowskich nauczycielach religii zatrudnianych przez daną szkołę nie zawsze bowiem znajdowały się w drukowanych sprawozdaniach, szematyzmach czy dziennikach urzędowych rady szkolnej. Należy wyrazić nadzieję, że przyszłe badania pozwolą uzupełnić i skorygować poczynione przez nas ustalenia, szczególnie w zakresie wskazania kolejnych przykładów Żydówek nauczających religii i zaprezentowania ich sylwetek.

${ }^{1}$ Zob.: Mirosław Łapot, Nauczycielki religii mojżeszowej w szkołach publicznych w Galicji w latach 1867-1939, „Prace Naukowe Akademii im. Jana Długosza w Częstochowie. Pedagogika" 20 (2011), s. 407-418. Mimo tak szeroko zarysowanego tematu problemowi nauczycielek w okresie autonomicznym poświęcono w tekście zaledwie kilka zdań (głównie s. 411 i 413), skupiając się raczej na okresie międzywojennym i zagadnieniach ogólnych, jak np. pozycja kobiet w judaizmie. Myląca może być przyjęta w tytule data 1867, sam autor datuje bowiem pojawienie się kobiet w szkołach na lata dziewięćdziesiąte XIX w.

2 Mirosław Łapot, Religia mojżeszowa w szkolnictwie publicznym we Lwowie w okresie autonomii galicyjskiej (1867-1918), Częstochowa 2019, s. 146-149. 


\section{Kobiety nauczycielki}

Żydówki nauczycielki religii były w okresie autonomii Galicji absolutną mniejszością pośród nauczających tego przedmiotu. Szematyzmy wykazują łącznie 12 kobiet i około 350 mężczyzn nauczających „religii mojżeszowej” w szkołach publicznych (przy czym nie uwzględniają one mełamedów pracujących w nadal funkcjonujących w tamtym okresie chederach). Kobiety stanowiły zatem niewielki odsetek przedstawicieli tej grupy zawodowej ${ }^{3}$. Jeśli weźmiemy pod uwagę wyłącznie statystyki dla początku XX w. ze szkół ludowych i fundacyjnych, odsetek kobiet okaże się nieco wyższy, chociaż nadal były one zdecydowaną mniejszością. Według obliczeń Mirosława Łapota czy Kazimierza Rędzińskiego w szkołach tych nauczało wówczas łącznie 116 nauczycieli, w tym 5 kobiet $^{4}$.

Żydówki pracowały w kilku typach szkół: zarównow ludowych i wydziałowych, gdzie dominowały dzieci chrześcijańskie, jak i w świeckich szkołach żydowskich, tzw. szkołach „z prawem publiczności”, w których można było realizować obowiązek szkolny, a wśród uczniów byli wyłącznie Żydzi. Do końca okresu autonomicznego nie znajdujemy ich jednak w szkołach średnich, mimo iż zdobywały wyższe kwalifikacje (doktorat), które mężczyźnie otworzyłyby drzwi do posady w gimnazjum ${ }^{5}$.

${ }^{3}$ Wyliczenie oparte na analizie wszystkich szematyzmów do 1914 r. Ich opracowaniem pod kątem informacji o nauczycielach religii mojżeszowej zajmuje się Jolanta Kruszniewska w ramach prac w projekcie wymienionym w opatrzonym gwiazdką przypisie na początku artykułu.

${ }^{4}$ Obaj badacze podają tę samą informację, identycznie formułując wypowiedź: „Na początku XX wieku religii mojżeszowej nauczano w 63 szkołach ludowych oraz fundacyjnych [na terenie Galicji - dopisek tylko u Mirosława Łapota]. Lekcje prowadziło 116 nauczycieli religii, w tym 5 kobiet, co spotykało się z krytyką ortodoksów”. Nie odwołują się oni jednak ani do żadnego źródła, ani nawzajem do swoich badań. Ich artykuły ukazały się w zbliżonym okresie. Zob.: Kazimierz Rędziński, Wspótdziałanie polskich $i$ żydowskich nauczycieli w Galicji na przełomie XIX $i$ XX wieku (do 1918 r.), [w:] W kręgu dawnych $i$ wspótczesnych teorii wychowania. Uczeń - szkoła - nauczyciel, red. Katarzyna Dormus, Ryszard Ślęczka, Kraków 2012, s. 324; Łapot, Nauczycielki religii..., s. 411.

${ }^{5}$ Przykładem jest Sara (Salomea) Perlmutter, która w 1902 r. obroniła doktorat z filozofii na uniwersytecie w Bernie (zob.: Salomea Perlmutter, Karl Menger und die österreichische Schule der Nationalökonomie: Eine kritische Untersuchung der Hauptlehren, Berno 1902). Mimo uzyskanych kwalifikacji nadal w kolejnych latach nauczała w szkołach ludowych. Zob.: Centralne Państwowe Archiwum Historyczne Ukrainy we Lwowie [dalej: CDIAL], fond [dalej: f.] 178, opis [dalej: op.] 1, sprawa [dalej: spr.] 5923, k. 64-65; CDIAL, f. 178, op. 1, spr. 4714, k. 39-40. Sara Perlmutter pojawia się w spisach członków grona nauczycielskiego Szkoły Żeńskiej 4-klasowej Ludowej im. króla Jana Sobieskiego we Lwowie za rok szkolny 1906/1907 i 1912-1913 jako nauczycielka stała. Dalszych badań wymaga ustalenie, czy ubiegała się o posadę w szkołach średnich. 
Najwcześniejsze wzmianki źródłowe dotyczące działalności Żydówek na niwie edukacji religijnej w Galicji pochodzą z lat siedemdziesiątych XIX w. W tym okresie zdarzało się, że kobiety ubiegały się o tzw. świadectwa uzdolnienia do nauczania religii. Przykładowo, dokumentem takim legitymowała się pochodząca z Jarosławia Sara Kohl, która uzyskała go w 1879 r. od rabina Bernarda Löwensteina pracującego we lwowskiej synagodze postępowej ${ }^{6}$. Dwa lata później świadectwo takie otrzymała także Joanna Taubeles, dyrektorka Izraelickiej Szkoły Żeńskiej we Lwowie. Posiadanie takiego dokumentu nie zawsze wiązało się z podjęciem pracy nauczycielki religii. Przykładowo, w przypadku Joanny Taubeles nie mamy potwierdzenia w źródłach, że rzeczywiście nauczała tego przedmiotu. Sam fakt jednak, iż kobiety o takie dokumenty się ubiegały i je uzyskiwały, pokazuje ich aspiracje w tym zakresie i pośrednio potwierdza istnienie dla nich jakichś perspektyw zawodowych na tym polu.

Wspomniana wyżej Sara Kohl została zatrudniona w otwartej w 1879 r. Szkole 4-klasowej Miejskiej im. Tadeusza Czackiego we Lwowie. Sara Kohl, Elżbieta Pekel i Betty Schulbaum już w pierwszych latach działania tej szkoły (1879-1883) nauczały religii po 4-6 godzin tygodniowo ${ }^{8}$. Mirosław Łapot podaje nazwiska kolejnych jedenastu kobiet, które przed rokiem 1885, często przez krótki czas, nauczały w tej szkole religii. Były to: Rozalia Ambes, Gusta Feingeld, Karolina Finkelstein, Adela Gelb, Dorota Gottlieb, Gizela Kohlman, Cecylia Lubinger, Rozalia Rohn, Adela Pineles, Franciszka Rosenbach, Agata Schnepp 9 . Listę tę możemy uzupełnić o kolejne nazwiska: Eugenia Goldstaub (uczyła w roku 1884/85), Maria Krakauer (1885/86), Chana Off (1887-1889), Sara (Salomea) Perlmutter (1885/86 i 1887-1890), Chana (Anna) Perlmutter (1887-1890), Anna Schlifka $(1882 / 83)^{10}$.

W latach siedemdziesiątych XIX w. Żydówki zaczęły nauczać religii w nieżydowskich szkołach publicznych ${ }^{11}$. Pierwszą nauczycielką, o której

${ }^{6}$ CDIAL, f. 701, op. 2, spr. 335, k. 44.

${ }^{7}$ Planer $\mathrm{z}$ domu Taubeles Joanna recte Chane Rechel. Informacja podana w ankiecie służbowej sporządzonej w gminie żydowskiej. Zob.: CDIAL, f. 701, op. 2, spr. 1181, k. 29-30.

${ }^{8}$ CDIAL, f. 701, op. 2, spr. 335, k. 40-41. W szkole tej od razu po jej ukonstytuowaniu się zatrudniono wiele kobiet: cztery nauczycielki młodsze i siedem praktykantek, nie wszystkie oczywiście nauczały religii.

${ }^{9}$ Lapot, Religia mojżeszowa..., s. 147.

${ }^{10}$ CDIAL, f. 701, op. 2, spr. 335, k. 165; Państwowe Archiwum Obwodu Lwowskiego [dalej: DALO], f. 3, op. 1, spr. 3302, 3396, 3624.

${ }^{11}$ Należy zatem skorygować wyrażone przez Mirosława Łapota przypuszczenie, że kobiety zaczęły pracować, na zasadzie godzin nadliczbowych, w latach dziewięćdziesiątych XIX w. Por. Łapot, Nauczycielki religii..., s. 411. 
mamy wiarygodne dane źródłowe, była Teresa Dachtelberg. Od roku 1877 do 1880 wykładała ona religię w Szkole Wydziałowej Żeńskiej 3-klasowej połączonej ze Szkołą 4-klasową Pospolitą w Rzeszowie ${ }^{12}$. W tej samej szkole w późniejszym okresie pracowały także inne kobiety: Berta Kammerling (najpierw jako praktykantka, a w latach 1889-1895 jako tymczasowy nauczyciel religii mojżeszowej ${ }^{13}$ ) oraz Etta Goldreich, po mężu Finkowa (zatrudniona w latach $1899-1900^{14}$ i $1902-1903^{15}$ ). Ta ostatnia pracowała także w Szkole Żeńskiej 4-klasowej im. św. Jadwigi w Rzeszowie w latach 1900-1903 ${ }^{16}$. Dodatkowo, w ramach zastępstwa, od stycznia do marca 1901 r. pełniła funkcję wychowawczyni klasy pierwszej ${ }^{17}$.

Szematyzmy wykazują przynajmniej dwanaście kobiet nauczających religii mojżeszowej w szkołach publicznych do $1914 \mathrm{r} \cdot{ }^{18}$ Jako pierwsza pojawia się Eugenia Hochberg, która - będąc nauczycielką tymczasową została zatrudniona w 4-klasowej Szkole Ludowej Żeńskiej w Tarnowie (w tzw. szkole przy katedrze $)^{19} \mathrm{w} 1896$ r. Najprawdopodobniej zastępowała Pinkasa Baslera, który w kolejnych latach figuruje jako tamtejszy nauczyciel religii, ona zaś w tej samej placówce nauczała od 1897 r. innego przedmiotu ${ }^{20}$. Przypuszczalnie w zastępstwie pracowała też Lea Weiner w Szkole Etatowej Żeńskiej w Mielcu, ponieważ także ona - podobnie jak Eugenia Hochberg - została odnotowana jako nauczycielka religii tylko

${ }^{12}$ Szkoła kilkakrotnie ulegała przekształceniom i zmieniała nazwę. Jej początki wiążą się z końcem wieku XVIII, kiedy powstała Szkoła Główna w Rzeszowie, a przy niej klasa dla dziewcząt. Była określana jako Szkoła Panieńska, Żeńska Szkoła 4-klasowa, a od 1873 r. przyjęła nazwę Szkoły Miejskiej dla Dziewcząt. Od 1877 r. nosiła nazwę Szkoły Wydziałowej Żeńskiej 3-klasowej połączonej ze Szkołą 4-klasową Pospolitą. W 1901 r. została przekształcona w Szkołę Wydziałową 6-klasową Żeńską połączoną z 4-klasową Pospolitą i Praktycznym kursem robót ręcznych kobiecych im. św. Scholastyki. Zob. Archiwum Państwowe w Rzeszowie [dalej: APRz], zesp. 212, sygn. 71, s. 4.

13 Tamże, s. 10-12.

${ }^{14}$ APRz, zesp. 543, sygn. 38, s. 15.

15 Szematyzm Królestwa Galicji i Lodomerii z Wielkim Księstwem Krakowskim, KrakówLwów 1902, s. 629; Szematyzm..., 1903, s. 629.

${ }^{16}$ APRz, zesp. 543, sygn. 38, s. 7-10, 12.

17 Tamże, s. 8.

${ }^{18}$ Szematyzmy zasadniczo zawierają informację o tym, że dany nauczyciel uczył religii czy to mojżeszowej, czy katolickiej (w przypadku innych przedmiotów takiej adnotacji nie ma). Gdy religia była dodatkowym nauczanym przedmiotem, informacji o jej nauczaniu nie podawano. Można to ustalić wyłącznie na podstawie innych źródeł, np. akt szkolnych.

19 Szematyzm..., 1896, s. 489.

${ }^{20}$ Jako nauczycielka tej szkoły jest wymieniana w kolejnych szematyzmach aż do $1905 \mathrm{r}$. Od roku 1907 do 1911 pracowała w Etatowej Szkole Żeńskiej im. Stanisława Konarskiego w Tarnowie. Biogramy sióstr Hochberg na potrzeby projektu opracowuje Bogusław A. Baczyński. 
w jednym roku ${ }^{21}$. Nauczycielką religii była również siostra Eugenii, Pauline Hochberg, która w 1900 r. pracowała w Szkole Pospolitej Męskiej 4-klasowej na Grabówce w Tarnowie 22 . Dwa lata później jej nazwisko figuruje w spisach nauczycieli religii mojżeszowej w 4-klasowej Szkole Ludowej Żeńskiej w Tarnowie ${ }^{23}$. Pauline nauczała w tarnowskich szkołach do 1917 r., kiedy to została przeniesiona w stan spoczynku ${ }^{24}$. W 1903 r. otrzymała etat stałego nauczyciela religii w 4-klasowych Szkołach Żeńskich im. Stanisława Konarskiego i Stanisława Staszica w Tarnowie. Zaniepokoiło to Majera Bałabana, który na łamach czasopisma „Wschód” opublikował artykuł pt. O nauke religii dotyczący niespójnych zasad udzielania kwalifikacji nauczycielom religii, w którym punktem wyjścia było niedawne zatrudnienie kobiety na stałą posadę nauczycielską ${ }^{25}$. Choć Bałaban zanonimizował jej dane - pisał o „pannie N. N. w T.” - z pewnością jednak możemy identyfikować ją jako Pauline Hochberg, ponieważ autor powołał się na konkretny numer Dziennika Urzędowego Rady Szkolnej Krajowej, gdzie ogłoszono nominację ${ }^{26}$.

Kilka lat później, w 1907 r., stałą posadę posiadały dwie kobiety odnoszono się do tego podczas posiedzenia we Lwowie ankiety w sprawie nauczania religii mojżeszowej ${ }^{27}$. Nie wymieniano ich z nazwiska, należy jednak zakładać, że chodziło o wspomnianą Pauline Hochberg i zapewne o pracującą w Przemyślu Antoninę Wolfównę ${ }^{28}$. Ponadtow 1907 r. posadę stałego nauczyciela religii mojżeszowej otrzymała Debora Rosner ${ }^{29}$.

${ }^{21}$ Tamże, s. 555.

${ }^{22} \mathrm{~W}$ tym samym czasie jako nauczyciel w tej szkole wykazany jest też Majer Taubeles, który uczył również w innych szkołach w mieście - zob. tamże, s. 591.

${ }_{23}$ Szematyzm..., 1902, s. 651. Już wcześniej jest wymieniana jako pracownica tej szkoły (zob.: Szematyzm..., 1901, s. 592, jednak bez adnotacji, że naucza religii).

24 „Dziennik Urzędowy C.K. Rady Szkolnej Krajowej w Galicyi” [dalej: „Dziennik Urzędowy C.K. RSK”], R. 21 (1917), nr 2, s. 9.

${ }^{25}$ Majer Bałaban, O naukę religii, „Wschód” (1903), nr 150, s. 3-5. Opierając się na artykule Bałabana, Mirosław Łapot wskazuje, że pierwsza nauczycielka na posadzie stałej została zatrudniona w Galicji w 1903 r., nie podaje jednak jej nazwiska - zob. Łapot, $\mathrm{Na}$ uczycielki religii..., s. 411.

${ }^{26}$ „Dziennik Urzędowy C.K. RSK”, R. 7 (1903), nr 24, s. 350.

${ }^{27}$ Sprawozdanie $z$ posiedzeń ankiety $w$ sprawie nauki religii mojżeszowej $w$ szkołach galicyjskich, odbytej dnia 11. lutego 1907, Lwów 1907.

28 Jako nauczycielka w przemyskich szkołach notowana jest w szematyzmach od 1902 r.; w 1905 r. została mianowana nauczycielką w 5-klasowej Szkole Wydziałowej Żeńskiej połączonej z 4-klasową Pospolitą w Przemyślu. Zob. „Dziennik Urzędowy C.K. RSK”, R. 9 (1905), nr 17, s. 222. Być może oznaczało to nominację na posadę stałą, wymaga to jednak dalszych badań. Zakładamy, że jest drugą spośród dwóch nauczycielek wspomnianych w 1907 r., ponieważ oprócz Pauline Hochberg jedynie ona była odnotowana w szematyzmach jako aktywna na polu nauczania religii w tym roku.

${ }^{29}$ „Dziennik Urzędowy C.K. RSK”, R. 11 (1907), nr 9, s. 1. 
Pod koniec pierwszej dekady XX w. i na początku następnej uzyskały posady kolejne kobiety: Eleonora Reicherowa w Szkole Wydziałowej Żeńskiej 5-klasowej im. św. Jadwigi w Nowym Sączu (od 1909)º ${ }^{30}$, Debora Erbowa w 5-klasowej Wydziałowej Szkole Żeńskiej im. Franciszka Józefa w Wadowicach (od 1911) ${ }^{31}$, Laura Beer w 4-klasowej Szkole Żeńskiej im. św. Kingi w Stryju (od 1912) ${ }^{32}$, Lea Ostreger w Etatowej Szkole Mieszanej w Peczeniżynie (od 1912) 33 oraz, w tej samej szkole, Chewed Schlosserówna $(\text { od 1913) })^{34}$, a także Chana Gross w Szkole Etatowej 4-klasowej połączonej z Wydziałową 3-klasową Szkołą w Wadowicach (od 1914) 35. W 1913 r. w czasopiśmie „Wychowanie i Oświata” podawano, że w Galicji stałe posady nauczycielek religii mojżeszowej posiadają kobiety w Przemyślu, Tarnowie, Nowym Sączu, Stryju i Wadowicach. W tym samym tekście wzmiankowano także o nauczycielkach „prowizorycznych” (tj. tymczasowych), których personalia trudniej jest ustalić, gdyż ich nazwiska nie są ujęte ani w szematyzmach, ani w sprawozdaniach szkolnych ${ }^{36}$.

Kobiety nauczały także religii w szkołach Fundacji Barona Hirscha (tzw. hirszówkach), chociaż na tym etapie badań znamy niewiele szczegółów na ten temat. O zatrudnianiu kobiet w tych szkołach dowiadujemy się z podania Fryderyki Bringsowej, która w 1917 r. zwracała się prośbą do Rady Gminy we Lwowie o udzielenie jej posady nauczycielki religii mojżeszowej w szkole im. Tadeusza Czackiego, argumentując że „uczyła religii przez lat 10 w szkołach Fundacji Barona Hirsza w Tarnowie i Bohorodczanach, ma odpowiednie kwalifikacje do nauki tego przedmiotu, zna język hebrajski" ${ }^{37}$.

Od końca XIX w. pojedyncze kobiety prowadziły też własne szkoły religijne przeznaczone dla dziewcząt - chedery. W latach dziewięćdziesiątych XIX w. funkcjonował cheder Rywki Mettalman w Krakowie ${ }^{38}$. We Lwowie

${ }^{30}$ O jej nominacji informowano w grudniu 1909 r. w „Nowej Reformie”, gdzie zawiadamiano o nominacji, podając inicjał imienia „L.” (zapewne Leonora) i nazwisko w brzmieniu „Reicherówna” - zob. Mianowania i przeniesienia, „Nowa Reforma” 28 (1909), nr 559, s. 3; w szematyzmie notowana jest w roku kolejnym.

${ }^{31}$ Szematyzm..., 1911, s. 813.

32 Szematyzm..., 1912, s. 794.

${ }^{33}$ Tamże, s. 748.

${ }^{34}$ Szematyzm..., 1913, s. 816.

35 Szematyzm..., 1914, s. 897. Przy Chanie Gross pojawia się informacja, że jest nauczycielką tymczasową, pracuje jako zastępca nauczyciela religii mojżeszowej.

${ }^{36}$ Naftali Schipper, Nauczycielka religii, „Wychowanie i Oświata” (1913), nr 79, s. 2-3.

${ }^{37}$ CDIAL, f. 701, op. 2, spr. 956, k. 2-3.

${ }^{38}$ Katarzyna Pabis-Cisowska, Postęp kontra tradycja. Kwestia matżeństwa, dobroczynności i szkolnictwa w żydowskim Krakowie na przełomie XIX i XX w., Kraków 2019, s. 274. 
siostry Ewa (Chawa) Terner i Anna Mensch otrzymały w listopadzie 1904 r. koncesję na otwarcie chederu w mieszkaniu Ewy Terner, które znajdowało się przy ul. Strzeleckiej $10^{39}$. Zastrzegano jednak, że Terner może uczyć jedynie języka hebrajskiego, nie posiada bowiem kwalifikacji do nauczania religii. Z przedstawionego do zatwierdzenia planu zajęć wynikało, że w chederze nauka miała zostać podzielona na trzy oddziały i zamierzano korzystać z podręcznika Judy Grazowskiego ${ }^{40}$.

Pod koniec okresu autonomicznego, na początku drugiej dekady XX w., udział kobiet w dydaktyce religii był zatem faktem. Źródła sugerują, że ich obecność w edukacji religijnej różniła się w zależności od regionu czy miasta. Choć na tym etapie badań wiadomo zdecydowanie za mało, by to potwierdzić, wydaje się, że były miejscowości, gdzie zatrudniano kobiety chętniej (jest to o tyle możliwe, że decyzja o powierzeniu posady należała do zarządu gminy). Do takich należeć mogły Tarnów, Rzeszów czy Wadowice ${ }^{41}$. Z kolei we Lwowie kobiety nauczały raczej w szkołach żydowskich niż w szkołach ogólnych. W 1913 r. Schipper pisał z zadowoleniem: „Lwowski zbór Izrael. dotychczas żadnej kobiecie nie zezwolił na uczenie religii w szkołach publicznych. I całkiem słusznie"42.

\section{Ramy prawne}

Decyzję o zatrudnieniu danej osoby na stanowisku nauczyciela religii mojżeszowej podejmowała rada gminy żydowskiej, która prezentowała daną kandydaturę Radzie Szkolnej Krajowej do zatwierdzenia. Podstawę prawną umożliwiającą zatrudnienie kobiet dawała ustawa z 1889 r. dotycząca wynagradzania nauczycieli religii, gdzie pojawiło się neutralne

${ }^{39}$ Kronika, „Wschód” (1904), nr 49, s. 5; DALO, f. 3, op. 1, spr. 4902, [b.p.]. Jeśli cheder funkcjonował, to krótko, już bowiem w 1906 r. stwierdzono, że Terner nie mieszka pod tym adresem.

${ }^{40}$ CDIAL, f. 701, op. 2, spr. 1375, k. 8. Z dokumentów nie wynika, czy podobne zastrzeżenia dotyczyły Anny Mensch.

${ }^{41}$ Co pokazują wymienione wyżej przykłady nauczycielek z tych miast. Nasze badania nie objęły jednak wszystkich ośrodków, możliwe więc, że przedstawione tu ustalenia zostaną skorygowane w przyszłych analizach opartych na kwerendach w aktach szkolnych.

${ }^{42}$ Schipper, Nauczycielka religii... Warto nadmienić, że Schipper nie do końca miał rację. W 1897 r. Cecylia Bardach otrzymała zgodę od rabina Jecheskela Caro na nauczanie religii w ramach zastępstwa (przynajmniej na pół roku i tylko w klasach 1-3) do czasu, aż posada zostanie ustabilizowana i znajdą nauczyciela religii w nowo otwartej Szkole Żeńskiej im. Tadeusza Kościuszki we Lwowie. Zob. CDIAL, f. 701, op. 2, spr. 956, k. 14-15. 
płciowo sformułowanie o „osobach” wykładających ten przedmiot ${ }^{43}$. Bezpośredniego wpływu na podejmowane decyzje nie mieli zatem środowisko nauczycielskie czy rabin, chociaż oczywiście zdarzało się konsultowanie z nimi wyboru. Frustrowało to zresztą przedstawicieli środowiska nauczycielskiego. W 1913 r. jeden z jego liderów, Naftali Schipper, pomstował: „Ci żydzi, którzy zasiadają w Przełożeństwach i do tego dopuszczają [do mianowania kobiet], odpowiedzą kiedyś przed Bogiem. Ci, co to czynią, na tem większe zasługują potępienie, im świadomiej dopuścili się tego" ${ }^{44}$.

Problem zatrudniania kobiet na stanowisku nauczycieli religii został podniesiony podczas tzw. ankiety w sprawie nauki religii mojżeszowej w 1907 r. Była to konferencja poświęcona problemom nauczania tego przedmiotu, w której brali udział przedstawiciele Rady Szkolnej Krajowej, reprezentanci gmin żydowskich, inspektorzy szkolni i uznani nauczyciele religii. Podczas obrad temat kobiet nauczycielek religii wywołał Mieczysław Zaleski, inspektor RSK, który wspomniał, że niekiedy rady wyznaniowe proponują kobiety na te stanowiska i wystosował pytanie, czy jest to dopuszczalne z religijnego punktu widzenia. Zaznaczał przy tym, że po prostu chce zasięgnąć opinii („Chciałbym usłyszeć zdanie w tej sprawie. Nie będzie ono mogło nas wiązać, bo my mamy na to ustawy. Ale radzi byśmy usłyszeć zdanie ankiety" ${ }^{45}$. Odpowiedź na jego pytanie, udzielona przez obecnego na obradach rabina i kaznodzieję Jecheskela Caro, była zwięzła: „Nie można!”. Uczestnicy obrad byli jednak zgodni co do tego, że kobiety, które już mają posady, należy na nich pozostawić. W przyszłości „problem” ich zatrudniania miał się niejako sam rozwiązać. Planowano bowiem otworzyć proseminarium teologiczne, którego ukończenie miało być wymogiem wobec przyszłych nauczycieli religii. Jak wyjaśniał Leon Sternbach:

proseminarium nie przyjmie żadnej kobiety. Więc kobieta nie otrzyma kwalifikacyi i nie będzie mogła być wskutek tego zamianowaną [...] Będą mogli być mianowani tylko ci, którzy wyjdą z tego zakładu, a ponieważ wyjdą tylko mężczyźni, a nie kobiety, sprawa będzie zupełnie jasną ${ }^{46}$.

${ }^{43}$ Ustawa z dnia 1 grudnia 1889 dla Królestwa Galicyi i Lodomeryi wraz z Wielkim Księstwem Krakowskiem, „Dziennik Ustaw i Rozporządzeń Krajowych dla Królestwa Galicyi i Lodomeryi wraz z Wielkiem Księstwem Krakowskiem” (1889), nr 71, s. 288.

${ }^{44}$ Schipper, Nauczycielka religii..., s. 2.

${ }^{45}$ Sprawozdanie z posiedzeń ankiety..., s. 38.

46 Tamże. 
Ton wypowiedzi podczas obrad ujawnia jednoznacznie negatywny stosunek zmaskulinizowanego środowiska nauczycielskiego do zatrudniania kobiet. Do ustaleń ankiety odwoływano się w kolejnych latach, postulując niezatrudnianie kobiet. W kręgach tych próbowano też (bezskutecznie) wykazywać, że ustawa z 1889 r. wcale nie umożliwia zatrudniania kobiet, a powierzanie im posad jest wynikiem mylnej interpretacji jej zapisów ${ }^{47}$.

\section{Kontrowersje wokół mianowania kobiet}

W styczniu 1914 r. Fryderyka Lazarus (1879-1942) otrzymała od zarządu lwowskiej gminy żydowskiej pozwolenie na nauczanie przez jeden semestr religii w prywatnej szkole ludowej Józefy Czarnockiej, ale tylko do czasu zatrudnienia innego nauczyciela. Przeciwko tej zgodzie ostro wystąpił rabin postępowy i jednocześnie inspektor szkolny dla religii mojżeszowej, dr Samuel Wolf Guttman, który wymieniał trzy główne powody, z których nie powinno się dopuścić Fryderyki Lazarus do nauczania tego przedmiotu: po pierwsze, „nie odpowiada ani duchowi religii żydowskiej, ani utartemu zwyczajowi, aby kobieta udzielała nauki religii”; po drugie, Lazarus nie posiadała (zdaniem Guttmana) odpowiednich kwalifikacji; po trzecie zaś było dużo „ukwalifikowanych mężczyzn”, którzy mogliby objąć tę posadę ${ }^{48}$.

Stwierdzenia Guttmana są warte przywołania, ponieważ odnoszą się do trzech motywów, które najczęściej pojawiały się w dyskusjach na temat powierzania posad kobietom, toczących się w pierwszej dekadzie i na początku drugiej XX w. Wśród argumentów, które wówczas wysuwano, były bowiem po pierwsze - niezgodność z tradycją, po drugie - rzekomy brak

47 Józef Steckel, Nauczycielka religii. Ustawowa niedopuszczalność mianowania żeńskich sit dla nauczania religii, „Wychowanie i Oświata” 9 (1914), nr 81, s. 5-6. Autor tego relatywnie długiego, kazuistycznego tekstu próbował dowodzić, że sformułowania ustawy odnoszą się wyłącznie do mężczyzn. Charakterystycznym przykładem tej kazuistyki jest następujący akapit: „Ze stylizacji paragrafu tego, mianowicie ze słowa »osoby« wnioskowano, jakoby nauczycie la mi religii izr. mogły być i kobiety. Tymczasem wystarczy tylko z uwagą przeczytać ten paragraf, aby się przekonać o mylności takiej interpretacyi. Powiedziane jest bowiem tam: »osoby, które złożyły egzamin na rabina, lub też które mają kwalifikację na nauczycieli szkół ludowych «. Wiadomo zaś, że żadna osoba żeńska nie może złożyć egzaminu na rabina, ani mieć kwalifikacyi na nauczyciela szkół ludowych, tylko na nauczycielkę szkół ludowych" (rozstrzelony druk jak w oryginale).

${ }^{48}$ CDIAL, f. 701, op. 2, spr. 956, k. 4. Zarząd gminy jednak nie uwzględnił argumentów Guttmana i udzielił Fryderyce Lazarusowej pozwolenia na nauczanie religii. Być może nie bez znaczenia był tu fakt, że pretendentka była córką Maurycego Lazarusa, który dekadę wcześniej wybudował dla gminy nowoczesny szpital. 
kompetencji kobiet, i po trzecie - sprawiedliwość społeczna (przy małej liczbie posad powierzanie ich kobietom postrzegano jako niesprawiedliwe).

Artykuły na ten temat, niekiedy pełne emocji, znajdujemy na łamach „Wychowania i Oświaty”, organu prasowego Towarzystwa Nauczycieli Religii Mojżeszowej Szkół Ludowych i Wydziałowych w Galicji, którego ukonstytuowanie się i działalność przypada na pierwszą dekadę XX w. Był to czas, kiedy obecność kobiet w dydaktyce religii mojżeszowej coraz wyraźniej się zaznaczała. Na posiedzeniach Towarzystwa kilkakrotnie debatowano nad problemem powierzania im stanowisk $^{49}$, a w przeciwdziałaniu ich nominacjom, czyli utrudnianiu im wejścia do zawodu, Towarzystwo upatrywało jednej ze swoich zasług ${ }^{50}$.

Ta postawa wiązała się z wyrażanym kilkakrotnie na łamach „Wychowania i Oświaty" przekonaniem, że zatrudnianie kobiet na stanowiskach nauczycielskich ,jest niezgodne z duchem judaizmu”, „,niezgodne z tradycją” czy wręcz „przeciwne uczuciom tradycyjnym i naturalnym”. W celu wykazania tego przywoływano argumenty z Talmudu, na przykład słynne, ostre słowa Eliezera ben Hyrkana sprzeciwiającego się kobiecym studiom nad tekstami religijnymi i prawem. Jak zauważał jeden z autorów: „zawołał znany nam ze swej skromności i łagodności mędrzec Eliazar syn Hyrkana: »Mądrością niewiasty jest wrzeciono; niech spalą raczej słowa Nauki świętej, aniżeli mają powierzyć nauczanie ich niewiastom «"51. Autor cytowanego tu artykułu w swoich rozważaniach próbował też wyjść poza kontekst żydowski i pokazać czytelnikom podrzędną pozycję kobiet w innych wyznaniach. Wskazywał na przykład na nieobecność kobiet w strukturach Kościoła katolickiego, która - jego zdaniem - była źródłem siły tej instytucji („Historya wykazuje, że kościół powszechny kierowany przez XX wieków silną dłonią mężów bez wmieszania się kobiet w sprawy jego, wyszedł dzięk[i] temu prawu ze wszystkich herezyi zwycięsko" ${ }^{52}$ ). Rozważania podsumował sformułowaniem: „A więc kobieta według istniejących przepisów wszelkich wyznań, nie kwalifikuje się do zajmowania stanowiska duszpasterza dla młodzieży"53.

49 [Posiedzenie z 27 grudnia], „Wychowanie i Oświata” 4 (1909), nr 33, s. 254.

50 Sprawozdanie z Walnego Zgromadzenia Tow. galicyjskich nauczycieli religii mojż. szkót posp. $i$ wydziat. odbytego dnia 1. listopada 1908 w sali Zboru izr. w Stanisławowie, „Wychowanie i Oświata” 3 (1908), dodatek do nru 31-32, [b.p.].

${ }^{51}$ Kilka słów o powierzaniu nauki religii niewiastom, „Wychowanie i Oświata” 2 (1907), nr 12, s. 95.

${ }^{52}$ Tamże, s. 95.

${ }^{53}$ Tamże (podkreślenie jak w oryginale). 
Drugim najczęstszym motywem, jaki pojawiał się w dyskusjach, był rzekomy brak kompetencji kobiet. W cytowanym już artykule drukowanym na łamach „Wschodu” Majer Bałaban, wówczas jeden z aktywnych członków środowiska nauczycielskiego, odwoływał się do ich zwyczajowego braku wykształcenia religijnego. Nie twierdził bynajmniej, że wszyscy nauczyciele mężczyźni posiadają wysoką wiedzę z zakresu judaistyki (przeciwnie, krytykował ich słabe przygotowanie), zauważał jednak istnienie dysproporcji w tym zakresie:

A wiedza żydowska! Nie wiele jej mają nasi nauczyciele, a co dopiero nasze nauczycielki. Zarzut to ciężki, ale uzasadniony. Wszak nauczyciel uczył się hebrajskiego będąc jeszcze chłopakiem i trochę mu tego (są i wyjątki) w głowie zostało, a dziewczęta żydowskie, one nigdy się tego nie uczyły, nigdy nie umiały i teraz mają wszczepić w dziecko nasze, to, czego same nie znają ${ }^{54}$.

Podobną, jednak bardziej rozbudowaną argumentację przedstawił w 1913 r. Naftali Schipper. W tekście wymieniał typowe braki w wykształceniu kobiet:

kobieta żydowska nie czyta biegle po hebrejsku, nie umie i nie może odmawiać przepisanych modłów i nie rozumie ich [...] nie przerobiła nawet Pięcioksięgu w oryginale, a tem mniej Proroków, nie zna objaśnienia Biblii Rasziego, nie zna najkrótszego kodeksu religijnego, który pod nazwą Szulchan-aruch obowiązuje do tej chwili wszystkich żydów ${ }^{55}$.

Autor robił rozróżnienie między Żydówkami z „prostych domów żydowskich” a pochodzącymi z „domów postępowych”. Nie pochwalał nadawania posad przedstawicielkom żadnej z tej grup, podkreślał jednak, że te drugie, nie mając „pojęcia o żydostwie ani teoretycznie, ani praktycznie”, mogą szczególnie zaszkodzić nauce religii: „Jeżeli taka właśnie dziewczyna [z postępowego domu] otrzymuje stałą posadę nauczycielki religii, wtedy biada nauce religii”" 56 .

Po trzecie, wśród argumentów pojawiały się te odwołujące się do specyficznie pojętej „sprawiedliwości społecznej”. Na przełomie wieków zdobycie stałej posady nauczycielskiej z zakresu nauczania religii mojżeszowej nie było łatwe, posad tych było bowiem niewiele. Kobiety traktowano w zmaskulinizowanym środowisku nauczycielskim jako niepożądaną konkurencję i zagrożenie pozycji mężczyzn, którym w opinii tego środowiska posady te

\footnotetext{
${ }^{54}$ Bałaban, O naukę religii..., s. 3-5 (pisownia w cytacie zgodna z oryginałem).

${ }_{55}$ Schipper, Nauczycielka religii..., s. 2.

56 Tamże.
} 
się po prostu należały. W 1912 r. na łamach „Wychowania i Oświaty” autor utyskiwał, że często nauczyciele religii mojżeszowej nie mogą się wydostać z małych ośrodków i uzyskać zatrudnienie w większej miejscowości (co było postrzegane jako awans): „Nauczyciel taki ciągle szuka ogłaszanych konkursów w nadziei przeniesienia się do innych miejscowości. Pisze podanie, daje stemple, a tymczasem posadę w II klasie płac zajął młody kolega, albo nauczyciel szkoły fund. Br Hirscha, albo nawet nauczycielka!"57. Ten sam motyw pojawił się kilka miesięcy później w artykule programowym Nasze postulaty wydrukowanym na pierwszej stronie czasopisma. W ostrych słowach („są to stosunki wprost horrendalne”) redakcja pisała o „starszych nauczycielach religii mojżeszowej”, którzy siedzą w małych miasteczkach, „bez nadziei dostania się do większego miasta, w którem mogliby swe dzieci kształcić”. Jako „zabierające” im posady na pierwszym miejscu wymieniał autor kobiety, oprócz młodych nauczycieli i nauczycieli hirszówek ${ }^{58}$. Dwa lata później na łamach tego samego czasopisma pisano o „rugowaniu” przez kobiety nauczycieli mężczyzn i krytykowano zwracanie się do kobiet w ogłoszeniach dotyczących posad (było to nawiązanie do konkretnego konkursu, o czym dalej). Autor artykułu w katastroficznym tonie pisał, że jest to niebezpieczne, ponieważ „wszędzie znajdą się łatwo z góry protegowane i przeznaczone nauczycielki, które pomału wyrugują ze wszystkich miast nauczycieli". Zatrudnianie kobiet nazywano wprost „zamachem na nasz [nauczycieli mężczyzn] szczupły stan posiadania" ${ }^{59}$.

\section{Kwalifikacje zawodowe kobiet}

Niewiele wiemy jeszcze o biografiach poszczególnych nauczycielek, ich edukacji i o tym, gdzie same zdobywały wiedzę religijną pozwalającą im następnie na nauczanie tego przedmiotu. Wiedza ta była poświadczana „Świadectwami uzdolnienia”, a niekiedy celującymi wynikami egzaminów na przykład siostry Mensch w 1903 r. zdały „z odznaczeniem egzamin z historii żydowskiej i języka hebrajskiego w wymiarze nauczycieli szkół ludowych i wydziałowych przed komisją rabinacką w łonie Zboru izraelickiego we Lwowie" $"$.

57 Przenoszenie nauczycieli religii, „Wychowanie i Oświata” 6 (1911), nr 55, s. 1.

${ }^{58}$ Nasze postulaty, „Wychowanie i Oświata” 6 (1911), nr 58-59, s. 1.

${ }^{59}$ Ms., Gtos nauczyciela z kraju. W sprawie konkursu na nauczycielke religii, „Wychowanie i Oświata" 9 (1914), nr 80, s. 2.

${ }^{60}$ Szkoła hebrajska dla dziewcząt żyd., „Wschód” (1903), nr 118, s. 9. 
Warto jednak w tym kontekście pamiętać, że w okresie autonomicznym żydowskie dziewczęta pobierały naukę religii w świeckich szkołach publicznych (wykładano ją w żeńskich szkołach wydziałowych, w których w ramach obowiązkowej edukacji religijnej Żydówki uczyły się religii mojżeszowej, a katoliczki miały katechezę), w żydowskich szkołach świeckich (tzn. takich szkołach, gdzie religia stanowiła tylko część curriculum, jak na przykład w szkole im. Czackiego we Lwowie czy w Izraelickiej Szkole Głównej w gmachu kazimierskiego ratusza). Przedmiot ten był także wykładany w żeńskich seminariach nauczycielskich - m.in. od początku obecny był w seminarium krakowskim, gdzie nauczał go Szymon Dankowicz, kaznodzieja synagogi postępowej (Tempel) ${ }^{61}$. We Lwowie w Seminarium Nauczycielskim Żeńskim lekcje religii dla dziewcząt żydowskich zostały wprowadzone później, dopiero w 1882 r., a przedmiotu tego nauczał Nechemiasz Landes ${ }^{62}$. Zdarzały się także nieliczne inne instytucje kształcące dziewczęta w zakresie zagadnień religijnych. Oczywiście nie można wyolbrzymiać znaczenia tych inicjatyw - obecność religii w szkołach świeckich była ograniczona do maksymalnie kilku godzin tygodniowo, a tradycyjnej edukacji religijnej dziewcząt nie poświęcano tyle samo uwagi, co męskiej.

Znaczna część kobiet nauczających religii pochodziła z rodzin, w których istniały tradycje nauczania tego przedmiotu - były żonami bądź córkami nauczycieli religii. Dzięki tym związkom mogły nabyć kompetencji w tym zakresie. Przykładem może być Joanna Planer, z domu Taubeles ${ }^{63}$, od 1879 r. żona Izaaka Planera, nauczyciela religii w wielu lwowskich szkołach, czy Rywka Mettalman, założycielka żeńskiego chederu w Krakowie. Mettalman była wdową po nauczycielu religii i ubiegając się o koncesję,

${ }^{61}$ Sprawozdanie Dyrekcyi c.k. Seminaryum nauczycielskiego żeńskiego w Krakowie za czas od r. 1872 do 1875, Kraków 1875, s. 18. Dankowicz uczył religii „w trzech kursach”, a także cztery godziny w „szkole ćwiczeń dla kandydatek”. W seminarium uczyło się rocznie kilkanaście Żydówek: w roku 1872 - 14 (na 103 katoliczki), w 1873 - 17 (na 101 katoliczek), w 1874 - 18 (na 94 katoliczki), w 1875 - 13 (na 104 katoliczki). W zakładzie uczyły się też pojedyncze osoby wyznania grekokatolickiego i ewangelickiego (jedna uczennica, najwyżej dwie rocznie). Zestawiono na podstawie statystyk z cytowanego tu sprawozdania. Zob. tamże, s. 30.

${ }^{62}$ I Sprawozdanie Dyrekcyi Seminaryum nauczycielskiego żeńskiego we Lwowie. Seminaryum Nauczycielskie Żeńskie we Lwowie 1871-1897, Lwów 1897, s. 22. Landes objął posadę w marcu $1883 \mathrm{r}$.

${ }^{63}$ Źródła wskazują, że posiadała uprawnienia, nie wiadomo jednak, czy nauczała. Joanna Taubeles była córką nauczyciela religii we Lwowie, Jakoba Taubelesa, i siostrą rabina i nauczyciela religii w Tarnopolu, Samuela Arona Taubelesa. Zob. CDIAL, f. 178, op. 2, spr. 1219, k. 22-23. 
wprost pisała, że kwalifikacje niezbędne do nauczania religii zdobyła dzięki praktyce, jeszcze za życia męża ${ }^{64}$. Ewa Terner, z domu Mensch, która w 1903 r. zdała z odznaczeniem egzamin, była żoną Dawida Eliasza Ternera, nauczyciela religii we Lwowie. Teresa Dachtelberg, nauczycielka religii w Rzeszowie, była córką Szymona (Seliga) Dachtelberga, który przez niemal dwie dekady nauczał religii w tamtejszym gimnazjum ${ }^{65}$. Także inna rzeszowska nauczycielka religii, Berta Kammerling, była z dużą dozą prawdopodobieństwa córką nauczyciela religii, Zygmunta Kammerlinga ${ }^{66}$. W jej przypadku wiemy też, jak wyglądało jej świeckie wykształcenie ogólne ukończyła Szkołę Wydziałową Żeńską w Rzeszowie, a także Państwowe Seminarium Nauczycielskie Żeńskie w Przemyślu ${ }^{67}$.

Przeciwnicy zatrudnienia kobiet na posadach nauczycieli religii z jednej strony krytykowali ich słabe przygotowanie, $\mathrm{z}$ drugiej jednak sami pośrednio przyznawali, że ich kompetencje mogą być równe tym, które posiadali mężczyźni. Na przykład Schipper w podsumowaniu długiego artykułu, gdzie przedstawiał argumenty przeciwko nominacji kobiet, pisał: „W razie zaś, jeżeliby kandydat i kandydatka mieli równą kwalifikację, posadę należy dać kandydatowi, a to ze względów religijnych" ${ }^{8}$.

\section{Zamiast podsumowania: sprawa konkursu w Podgórzu}

30 września 1913 r. Rada Szkolna Okręgowa w Podgórzu ogłosiła konkurs na obsadzenie stałej posady nauczycielskiej w Szkole Wydziałowej Żeńskiej im. Henryka Sienkiewicza w Podgórzu przy ul. Szkolnej (obecnie ul. Potiebni). W warunkach konkursu wprost napisano, że posada może zostać powierzona kobiecie lub mężczyźnie - szukano „nauczyciela względnie nauczycielki religii izraelickiej”. Informacja ta została w ogłoszeniu retorycznie podkreślona - przy omawianiu bowiem warunków zatrudnienia ponownie zaznaczano, że mogą się o nią ubiegać „kompetenci

${ }^{64}$ Pabis-Cisowska, Postep kontra tradycja..., s. 275.

${ }_{65}$ APRz, zesp.1, sygn. 276, s. 120.

${ }^{66}$ W kronice Publicznej Szkoły Żeńskiej im. św. Scholastyki zapisano:, „Berta i Józefa Kammerling - praktykantki i kwalifikowane freblówki z Rzeszowa”. Zob. APRz, zesp. 212, sygn. 71, s. 2; Józefa Kammerling była nieślubną córką Zygmunta Kammerlinga, który zapewnił jej odpowiednie wykształcenie i zabezpieczył finansowo, stąd też przypuszczenie, że skoro pojawiły się razem w kronice, mogły być ze sobą spokrewnione. Zob. Józef Świeboda, Edukacja Żydów w Galicji 1772-1918, „Prace Historyczno-Archiwalne” 2 (1994), s. 111.

67 Archiwum Państwowe w Przemyślu, zesp. 357, sygn. 41, s. 36.

${ }^{68}$ Schipper, Nauczycielka religii..., s. 3. 
lub kompetentki" ${ }^{69}$. Był to pierwszy i - jak się wydaje - jedyny konkurs rozpisany w okresie autonomicznym, gdzie w taki sposób sformułowano warunki. Dokumenty w konkursie można było składać do 31 grudnia 1913 r. Na początku 1914 r. redakcja „Wychowania i Oświaty” donosiła, że posada rzeczywiście zostanie powierzona kobiecie. Niestety nie udało się ustalić, kto ją otrzymał i czy faktycznie była to kobieta ${ }^{70}$.

Konkurs podgórski jest interesujący przede wszystkim z uwagi na reakcje, jakie wywołał. Ogłoszenie konkursowe wzbudziło spore kontrowersje w środowisku nauczycieli religii, a czasopismo „Wychowanie i Oświata" w kolejnych numerach drukowało artykuły poświęcone temu zagadnieniu. Jako pierwszy głos zabrał Naftali Schipper, prezes Towarzystwa Nauczycieli Religii Mojżeszowej Szkół Ludowych i Wydziałowych w Galicji, a także redaktor i wydawca „Wychowania i Oświaty”. W artykule, kilkakrotnie już wyżej cytowanym, jednoznacznie skrytykował zatrudnianie kobiet. Sekundował mu anonimowy autor, podpisujący się jako „Ms.”, który reprezentował środowisko nauczycielskie mniejszych ośrodków ${ }^{71}$. W artykule pt. Gtos nauczyciela z kraju, opublikowanym na pierwszych stronach czasopisma ${ }^{72}$, chwalił Schippera za „głos męski i stanowczy”, który „odbił się głośnem echem w szeregach nauczycielskich”. Autor wysuwał ponadto oskarżenie, że konkurs został ustawiony przez podgórską radę wyznaniową pod konkretną kandydatkę: „Konkurs [...] nasuwa przypuszczenie, że kandydatka jest z góry przez miejscowe władze przeznaczona i że nauczyciele a limine są pozbawieni możności uzyskania tej posady"73. Przede wszystkim jednak opisywał rozgoryczenie nauczycieli pracujących w małych ośrodkach, którzy nie mogą liczyć na lepsze posady. Swoim artykułem chciał się przyczynić do uświadomienia radom wyznaniowym trudnego położenia żydowskich nauczycieli religii. Sprawa zatrudniania kobiet służyła zatem przede wszystkim jako doskonały

69 „Dziennik Urzędowy C.K. RSK”, R. 17 (1913), nr 25, s. 496.

${ }^{70}$ Informacji o tej nominacji nie podają urzędowe źródła, takie jak „Dziennik Urzędowy C.K. RSK". Szematyzm za 1914 r. wskazuje, że funkcję tę nadal sprawował nauczyciel tymczasowy Leon Silberschütz zatrudniony w tej szkole od 1909 r., zob. Szematyzm ..., 1914, s. 828

${ }^{71}$ Wprost pisała o tym redakcja: „Głos tego nauczyciela z kraju jest głośnym echem i innych kolegów, zajętych w małych miastach”. Zob. Od Redakcji [dopisek pod artykułem Głos nauczyciela z kraju], „Wychowanie i Oświata” 9 (1914), nr 80, s. 3.

72 Artykuł ukazał się w pierwszym numerze czasopisma za 1914 r., zwyczajowo pierwszą stronę zajął więc tekst podsumowujący poprzedni rok. Artykuł dotyczący zatrudniania kobiet został opublikowany zaraz po nim, na s. 2 i 3.

${ }^{73}$ Ms., Gtos nauczyciela..., s. 2. 
pretekst do ożywienia dyskusji na ten temat (po raz kolejny, bo problem ten wracał od lat).

Kontrowersje wokół podgórskiego konkursu ujawniają, że w toczących się w środowisku nauczycielskim debatach nad zatrudnianiem kobiet bardziej niż o tradycję - czy nawet bardziej niż o dobro uczniów, na które tak chętnie się powoływano - mogło chodzić o utrzymanie i wzmocnienie pozycji nauczycieli mężczyzn. Innymi słowy, można przypuszczać, że gdyby stałych posad nauczycielskich było więcej, zatrudnianie kobiet nie budziłoby takich kontrowersji.

Reakcje środowiska nauczycielskiego na nominacje kobiet wydają się nieadekwatne do liczby kobiet faktycznie obecnych w dydaktyce szkolnej religii, chodziło w nich jednak raczej o cementowanie status quo, w którym formalne nauczanie jest domeną mężczyzn. Nie udało się to. Do końca okresu autonomicznego kobiety stanowiły wprawdzie małą grupę wśród nauczających religii, widać jednak, jak ich obecność się coraz bardziej zaznaczała i w pewnym sensie stawała się bardziej oficjalna. Pod koniec XIX w. pierwsza kobieta została odnotowana w szematyzmie, na początku XX w. pierwsza kobieta uzyskała stałą posadę, a dekadę później, w 1913 r., po raz pierwszy kobiety zostały ujęte w warunkach konkursu na posadę. Pozycja kobiet wzmocniła się do tego stopnia, że w międzywojniu były członkiniami ruchu nauczycielskiego.

\section{Bibliografia}

\section{1. Źródła archiwalne}

Archiwum Państwowe w Przemyślu

I Państwowe Seminarium Nauczycielskie Żeńskie w Przemyślu, zesp. 357, sygn. 41.

Archiwum Państwowe w Rzeszowie (APRz)

Akta miasta Rzeszowa, zesp. 1, sygn. 276.

Publiczna Szkoła Powszechna im. św. Jadwigi w Rzeszowie, zesp. 543, sygn. 38.

Publiczna Szkoła Żeńska im. św. Scholastyki w Rzeszowie, zesp. 212, sygn. 71.

Centralne Państwowe Archiwum Historyczne Ukrainy we Lwowie (CDIAL)

Gmina wyznaniowa żydowska we Lwowie, f. 701, op. 2, spr. 335, 956, 1181, 1375.

Rada Szkolna Krajowa, f. 178, op. 1, spr. 4714, 5923; op. 2, spr. 1219.

Państwowe Archiwum Obwodu Lwowskiego (DALO)

Magistrat miasta Lwowa, f. 3, op. 1, spr. 3302, 3396, 3624, 4902. 


\section{2. Źródła opublikowane}

\section{Prasa}

„Nowa Reforma” 1909.

„Wschód” 1903-1904.

„Wychowanie i Oświata” 1907-1909, 1911, 1913-1914.

\section{Inne źródła drukowane}

„Dziennik Urzędowy C.K. Rady Szkolnej Krajowej w Galicyi” 1903, 1905, 1907, 1913, 1917.

I Sprawozdanie Dyrekcyi Seminaryum nauczycielskiego żeńskiego we Lwowie. Seminaryum Nauczycielskie Żeńskie we Lwowie 1871-1897, Lwów 1897.

Sprawozdanie Dyrekcyi c.k. Seminaryum nauczycielskiego żeńskiego w Krakowie za czas od r. 1872 do 1875, Kraków 1875.

Sprawozdanie z posiedzeń ankiety $w$ sprawie nauki religii mojżeszowej w szkołach galicyjskich, odbytej dnia 11. lutego 1907, Lwów 1907.

Szematyzm Królestwa Galicji i Lodomerii z Wielkim Księstwem Krakowskim, Kraków_ Lwów 1896, 1901-1903, 1911-1914.

Ustawa z dnia 1 grudnia 1889 dla Królestwa Galicyi i Lodomeryi wraz z Wielkim Księstwem Krakowskiem, „Dziennik Ustaw i Rozporządzeń Krajowych dla Królestwa Galicyi i Lodomeryi wraz z Wielkiem Księstwem Krakowskiem”, nr 71, Lwów 1889.

\section{Opracowania}

Łapot Mirosław, Nauczycielki religii mojżeszowej w szkołach publicznych w Galicji w latach 1867-1939, „Prace Naukowe Akademii im. Jana Długosza w Częstochowie. Pedagogika” 20 (2011).

Łapot Mirosław, Religia mojżeszowa w szkolnictwie publicznym we Lwowie w okresie autonomii galicyjskiej (1867-1918), Częstochowa 2019.

Pabis-Cisowska Katarzyna, Postęp kontra tradycja. Kwestia matżenstwa, dobroczynności i szkolnictwa w żydowskim Krakowie na przełomie XIX i XX w., Kraków 2019.

Rędziński Kazimierz, Współdziałanie polskich $i$ żydowskich nauczycieli w Galicji na przełomie XIX i XX wieku (do 1918 r.), [w:] W kręgu dawnych i wspótczesnych teorii wychowania. Uczeń - szkoła - nauczyciel, red. Katarzyna Dormus, Ryszard Ślęczka, Kraków 2012.

Świeboda Józef, Edukacja Żydów w Galicji 1772-1918, „Prace Historyczno-Archiwalne" 2 (1994).

Alicja Maślak-Maciejewska, Uniwersytet Jagielloński alicja.maslak@uj.edu.pl

Anna Trzasalska, Uniwersytet Jagielloński ankadawidowicz@gmail.com

Maria Vovchko, badaczka niezależna mvovchko@gmail.com 